\title{
KAJIAN PELAYANAN ANTENATAL K4 DAN PERTOLONGAN PERSALINAN DI PUSKESMAS KABUPATEN PATI
}

\section{STUDY OF K4 ANTENATAL SERVICES AND DELIVERY ASSISTANCE AT THE PUSKESMAS IN PATI DISTRICT}

\author{
Ulin Nafiah'1)a), Indayana Setiawati2)b) \\ 1)Prodi DIII Kebidanan Akademi Kebidanan Duta Dharma Pati, \\ a)Jl. Raya Pati - Kudus Km. 6 Pati. 59163. Jawa Tengah \\ 2)Prodi DIII Kebidanan Akademi Kebidanan Muslimat NU Kudus \\ b)Jl. Lambau Karangsambung Kudus. 59333. Jawa Tengah
}

\begin{abstract}
The services of $K 4$ pregnant women are a complete range of antenatal services that meet minimum service standards. This study aim was to analyze the implementation of antenatal $\mathrm{K} 4$ in the Community Health Center of Pati District. This research used a qualitative approach with phenomenological evidents, to provide an overview of the experiences of midwives in antenatal $K 4$ and delivery assistance in community health centers in order to reduce MMR. The main informants were 5 midwives and triangulation including 2 head of the community health center, 2 doctors at the community health center, and 1 head of the family health section. The research used purposive sampling. The results showed that the K4 service at the community health center was carried out by midwives and doctors, with its operational application known as a minimum service standard (10T). Most childbirth assistance has been conducted at the community health center by midwives and doctors (on call). If complications are found in childbirth, the midwife will coordinate with the clinic doctor to make a referral letter. K4 coverage has not been fulfilled so it is necessary to promote K4 antenatal services to the community.
\end{abstract}

Keywords: K4 program, decrease MMR, childbirth assistance delvery

\begin{abstract}
ABSTRAK
Pelayanan ibu hamil K4 merupakan cakupan pelayanan antenatal secara lengkap yang memenuhi standar pelayanan minimal. Penelitian ini bertujuan untuk menganalisis pelaksanaan pelayanan antenatal K4 di Puskesmas Kabupaten Pati. Penelitian menggunakan pendekatan kualitatif dengan pendekatan fenomenologis, untuk memberikan gambaran tentang pengalaman bidan dalam program K4 dan pertolongan persalinan di Puskesmas dalam rangka menurunkan Angka Kematian Ibu (AKI). Informan utama 5 bidan dan triangulasi pada 2 Kepala Puskesmas, 2 dokter Puskesmas, dan 1 Kepala Seksi Kesehatan Keluarga. Teknik sampling menggunakan teknik purposive sample. Hasil penelitian menunjukkan bahwa pelayanan K4 di Puskesmas dilaksanakan oleh bidan dan dokter dengan penerapan operasionalnya dikenal standar pelayanan minimal (10T). Pertolongan persalinan sebagian besar sudah di Puskesmas oleh bidan dan dokter (on call). Jika ditemukan penyulit dalam persalinan, bidan akan berkoordinasi dengan dokter puskesmas untuk membuat surat rujukan. Cakupan K4 belum terpenuhi sehinggga perlu promosi pelayanan antenatal K4 kepada masyarakat.
\end{abstract}

Kata kunci: program K4, penurunan AKI, pertolongan persalinan

\section{PENDAHULUAN}

Kematian maternal (maternal mortality) suatu Negara atau daerah merupakan ukuran yang digunakan untuk menilai baik buruknya suatu keadaan pelayanan kebidanan (maternity care). Indikator yang umum digunakan adalah
Angka Kematian Ibu (Maternal Mortality Ratio) yaitu jumlah kematian ibu per 100.000 kelahiran hidup (Wiknjosastro, 2011).

Kematian dan kesakitan ibu masih merupakan masalah kesehatan yang serius di negara berkembang. Menurut laporan World Health Organization (WHO) tahun 2014, sekitar 99\% 
dari seluruh kematian ibu akibat masalah atau komplikasi selama kehamilan dan persalinan terjadi di negara berkembang. Angka kematian ibu (AKI) di dunia yaitu 289.000 jiwa. AKI di negara-negara Asia Tenggara yaitu Indonesia 214 per 100.000 kelahiran hidup, Filiphina 170 per 100.000 kelahiran hidup, Vietnam 160 per 100.000 kelahiran hidup, Thailand 44 per 100.000 kelahiran hidup, Brunei Darussalam 60 per 100.000 kelahiran hidup, dan Malaysia 39 per 100.000 kelahiran hidup. AKI di Indonesia menduduki angka tertinggi di negara Asia Tenggara (WHO, 2014).

AKI di Indonesia berdasarkan hasil Survei Penduduk Antar Sensus (SUPAS) Tahun 2015 yang dilakukan oleh Badan Pusat Statistik (BPS), tercatat mencapai 305 per 100.000 kelahiran hidup. Upaya percepatan penurunan AKI dapat dilakukan dengan menjamin setiap ibu mampu mengakses pelayanan kesehatan yang berkualitas. Salah satu pelayanan kesehatan yang penting bagi ibu adalah pelayanan ibu hamil dan pertolongan persalinan oleh tenaga kesehatan yang terlatih di fasilitas kesehatan (Key, 2018).

AKI di Jawa Tengah tahun 2017 sebanyak 88,05 per 100.000 kelahiran hidup. Sedangkan AKI tahun 2018 mengalami penurunan menjadi 78,60 per 100.000 kelahiran hidup. Kematian biasanya terjadi karena tidak mempunyai akses pelayanan kesehatan yang berkualitas serta keterlambatan mendapatkan pelayanan di fasilitas kesehatan (Dinkes Prov Jateng, 2019).

AKI di Kabupaten Pati dari tahun 2016 sampai tahun 2018 mengalami penurunan, meskipun tidak signifikan. AKI pada tahun 2016 sebanyak 20 orang (115,3 per 100.000 kelahiran hidup). AKI di tahun 2017 sebanyak 15 orang (85,87 per 100.000 kelahiran hidup). Adapun AKI pada tahun 2018 sebanyak 11 orang atau 66,07 per 100.000 kelahiran hidup (Dinkes Kab Pati, 2019).

AKI di Indonesia masih menjadi masalah yang harus segera ditangani oleh tenaga kesehatan. Antenatal care adalah suatu program yang terencana berupa observasi, edukasi, dan penanganan medik pada ibu hamil, untuk memperoleh suatu proses kehamilan serta persalinan yang aman dan memuaskan pada ibu hamil (Depkes RI, 2011). Salah satu upaya penurunan AKI yang dilakukan Kementerian Kesehatan Republik Indonesia adalah dengan kebijakan pelayanan antenatal K1 dan K4. Pelayanan antenatal penting untuk memastikan kesehatan ibu selama kehamilan dan menjamin ibu untuk melakukan proses persalinan di fasilitas kesehatan. Pelayanan K4 adalah pemeriksaan kehamilan yang keempat atau atau lebih, dengan petugas kesehatan yang kompeten. Tujuannya untuk mendapatkan pelayanan antenatal yang terpadu dan komprehensif sesuai standar (Kemenkes RI, 2012).

Pelayanan antenatal K4 dapat digunakan sebagai indikator penilaian kualitas pelayanan kesehatan ibu hamil. Indikator K4 merupakan indikator untuk melihat frekuensi pemeriksaan kehamilan pada periode trimester (Depkes, 2011). Hal ini dijelaskan juga dalam Permenkes No 4 Tahun 2019 tentang Standar Teknis Pemenuhan Mutu Pelayanan Dasar pada Standar Pelayanan Minimal (SPM) Bidang Kesehatan. Permenkes tersebut menyatakan SPM untuk cakupan kunjungan K4 sebesar 95\%.

Angka cakupan kunjungan ulang pemeriksaan ibu hamil menunjukkan besarnya akses atau jangkauan terhadap layanan kesehatan ibu hamil. Selain itu, angka kunjungan ibu hamil dapat menggambarkan peluang untuk mendeteksi dan menangani ibu hamil dengan risiko tinggi. Upaya peningkatan cakupan K4 memerlukan kesiapan petugas kesehatan yang berwenang, sarana prasarana pelayanan antenatal yang berkualitas serta proses yang dilakukan oleh pemberi layanan (Sumiati, 2012). Secara nasional, indikator kinerja cakupan pelayanan kesehatan ibu hamil K4 sebesar 88,03\% pada tahun 2018. Cakupan ini sudah melebihi target Rencana Strategis (Renstra) Kementerian Kesehatan tahun 2018 yaitu sebesar 78\% (Kemenkes RI, 2019).

Cakupan K4 di Provinsi Jawa Tengah sebesar 93,07\% pada tahun 2018. Angka tersebut belum bisa mencapai target nasional yaitu 95\%. Oleh karena itu, perlu upaya peningkatan 
pelayanan kesehatan terutama untuk ibu hamil dengan cara meningkatkan pelayanan antenatal secara lengkap dan sesuai standar (Dinkes Prov Jateng, 2019).

Data cakupan program K4 dari 29 Puskesmas di Kabupaten Pati menunjukkan bahwa adanya kenaikan dalam 2 tahun terakhir. Cakupan pelayanan lengkap ibu hamil (K4) di Kabupaten Pati tahun 2018 sebesar 98\%. Angka ini lebih tinggi dibandingkan tahun 2017 dan tahun 2016 yaitu masing-masing sebesar 95,1\%, dan 94,4\% (Dinkes Kab Pati, 2018), sehingga telah mencapai target yang ditentukan.

Hasil penelitian Rahmawati (2013) menyatakan bahwa ada beberapa faktor yang berpengaruh terhadap keberhasilan cakupan pelayanan antenatal, antara lain faktor tenaga kesehatan baik kualitas maupun kuantitasnya, sarana dan prasarana pelayanan kesehatan, ketersediaan dana, dan manajemen yang meliputi perencanaan, pembinaan, kerjasama, dan penilaian. Faktor yang paling berpengaruh dalam suatu tujuan yang sudah dirancang adalah faktor sumber daya manusia.

Berdasarkan latar belakang masalah tersebut, peneliti tertarik untuk melakukan penelitian tentang kajian pelayanan antenatal K4 dan pertolongan persalinan di Puskesmas Kabupaten Pati.

\section{TINJAUAN PUSTAKA}

\section{Kebijakan Publik}

Kebijakan publik (public policy), yaitu suatu aturan yang mengatur kehidupan bersama yang harus ditaati dan berlaku mengikat seluruh warganya. Setiap ada pelanggaran akan diberi sanksi sesuai dengan bobot pelanggaran yang dilakukan dan sanksi dijatuhkan di depan masyarakat oleh lembaga yang mempunyai tugas menjatuhkan sanksi (Nugroho R, 2014).

Robert Eyestone dalam Agustino (2016) mendefinisikan kebijakan publik sebagai suatu hubungan antara unit pemerintah dengan lingkungannya. Menurut Federick dalam Agustino (2016), kebijakan adalah serangkaian tindakan atau kegiatan yang diusulkan seseorang, kelompok atau pemerintah dalam suatu lingkungan tertentu dimana terdapat hambatanhambatan atau kesulitan-kesulitan dan kesempatan terhadap pelaksanaan usulan kebijakan tersebut dalam rangka mencapai tujuan tertentu.

\section{Kehamilan}

Kehamilan merupakan proses alami bukan proses patologis, tetapi kondisi normal yang dapat berubah menjadi patologis atau abnormal (Kusmiyati, 2010). Kehamilan juga didefinisikan sebagai fertilisasi atau penyatuan spermatozoid dan ovum, kemudian dilanjutkan dengan nidasi atau implantasi. Kehamilan normal akan berlangsung dalam waktu 40 minggu, terhitung dari saat fertilisasi hingga lahirnya bayi (Prawirohardjo, 2014).

\section{Kunjungan Antenatal K4}

Kunjungan antenatal K4 adalah kontak ibu hamil yang keempat atau lebih dengan petugas kesehatan yang mempunyai kompetensi untuk mendapatkan pemeriksaan kehamilan dan pelayanan terpadu serta komprehensif sesuai standar (Kemenkes RI, 2012).

Jenis pelayanan meliputi anamnesis, pemeriksaan fisik umum dan kebidanan, pemeriksaan laboratorium atas indikasi tertentu serta indikasi dasar dan khusus. Selain itu ada penyuluhan, KIE (Komunikasi, Informasi dan Edukasi), motivasi ibu hamil dan rujukan (Kemenkes RI, 2012).

Prawirohardjo (2014) menyatakan bahwa kunjungan antenatal sebaiknya dilakukan paling sedikit 4 kali selama masa kehamilan dengan distribusi kontak sebagai berikut: 1) minimal 1 kali pada trimester I (K1) pada usia kehamilan 1-12 minggu; 2) minimal 1 kali pada trimester II (K2) pada usia kehamilan 13-24 minggu; 3) minimal 2 kali pada trimester III (K3-K4) pada usia kehamilan $>24$ minggu.

Tujuan pemeriksaan K1-K4 dalam pelayanan antenatal adalah: 1) menjaga agar ibu sehat selama masa kehamilan, persalinan dan 
nifas serta mengusahakan bayi yang dilahirkan dalam keadaan sehat; 2) memantau kemungkinan adanya risiko kehamilan, serta sekaligus merencanakan penatalaksanaan yang optimal pada kehamilan risiko tinggi; 3) menurunkan morbiditas dan mortalitas ibu dan perinatal.

Standar pelayanan 10T yaitu: 1) timbang berat badan dan ukur tinggi badan; 2) ukur tekanan darah; 3) tentukan status gizi (ukur Lingkar Lengan Atas/LILA); 4) ukur tinggi fundus uteri; 5) tentukan presentasi janin dan denyut jantung janin; 6) skrining status imunisasi tetanus dan bila diperlukan berikan imunisasi Tetanus Toxoid (TT); 7) pemberian tablet tambah darah minimal 90 tablet selama kehamilan; 8) tes laboratorium (rutin dan khusus); 9) tata laksana kasus, 10) temu wicara (konseling), termasuk Perencanaan Persalinan dan Pencegahan Komplikasi (P4K) serta KB pasca persalinan (Kemenkes RI, 2012).

Tes laboratorium rutin terdiri dari tes rutin umum terdiri dari pemeriksaan $\mathrm{Hb}$ dan golongan darah. Tes rutin di daerah endemis atau epidemik meliputi tes malaria, tes HIV, dan tes Sifilis. Tes laboratorium khusus terdiri dari tes protein urine, BTA, hepatitis B, gula darah, tes urin, tes IMS, dan lain-lain (Kemenkes RI, 2012).

\section{Pertolongan Persalinan}

Persalinan adalah proses dimana bayi, plasenta dan selaput ketuban keluar dari uterus ibu (APN, 2014). Dikatakan persalinan normal jika prosesnya terjadi pada usia kehamilan 37-42 minggu atau usia cukup bulan tanpa disertai dengan penyulit (Nurasiah, 2013).

Pertolongan persalinan oleh tenaga kesehatan adalah persalinan yang ditolong oleh tenaga kesehatan seperti bidan, dokter, dan tenaga para medis lainnya. Tenaga kesehatan tersebut merupakan orang yang ahli dalam membantu persalinan, sehingga keselamatan ibu dan bayi lebih terjamin. Apabila terdapat kelainan dalam proses persalinan dapat segera diketahui dan dirujuk ke fasilitas kesehatan yang lebih memadai. Persalinan yang ditolong oleh tenaga kesehatan menggunakan peralatan yang aman, bersih, dan steril sehingga mencegah terjadinya infeksi dan bahaya kesehatan lainnya (APN, 2014).

\section{METODE PENELITIAN}

Penelitian ini merupakan penelitian kualitatif dengan pendekatan fenomenologis. Adapun tujuan penelitian adalah untuk menggambarkan pelaksanaan pelayanan antenatal K4 dan pertolongan persalinan di Puskesmas dalam rangka menurunkan AKI. Informan dipilih berdasarkan teknik purposive sampling dengan prinsip kesesuaian dan kecukupan. Penelitian kualitatif tidak mempersoalkan jumlah sampel, informan bisa sedikit atau bisa banyak tergantung dari tepat tidaknya pemilihan informan kunci dan kompleksitas serta keragaman fenomena yang diteliti (Moleong, 2013).

Pengumpulan data dilakukan melalui wawancara mendalam pada informan utama dan informan triangulasi. Informan utama terdiri dari 5 (lima) orang bidan koordinator Puskesmas, Informan triangulasi terdiri dari Kepala Seksi Kesehatan Keluarga Dinas Kesehatan Kabupaten Pati, Kepala Puskesmas dan satu orang dokter Puskesmas. Penelitian ini dilakukan di Puskesmas Kabupaten Pati. Pengolahan data terdiri dari content analysis, mengambil kesimpulan dan verifikasi, dan narasi dalam bentuk laporan hasil penelitian dengan metode deskriptif.

\section{HASIL DAN PEMBAHASAN}

\section{Gambaran Karakteristik Informan}

Informan dilihat berdasarkan usia, pendidikan dan masa kerja. Usia informan berada pada rentang $35-50$ tahun. Tingkat pendidikan informan bervariasi, tingkat pendidikan terendah D3 dan tingkat pendidikan tertinggi S2. Masa kerja pegawai terendah 4 tahun dan masa kerja tertinggi 24 tahun. Karakteristik informan berdasarkan usia, pendidikan, dan masa kerja disajikan secara lengkap dalam Tabel 1. 
Tabel 1.

Karakteristik Informan Penelitian

\begin{tabular}{|c|c|c|c|c|}
\hline Nama & Umur & Jabatan & Pendidikan & Masa kerja \\
\hline \multicolumn{5}{|c|}{ Informan Utama } \\
\hline $\mathrm{R}-4 \mathrm{a}$ & 45 th & BP Sukililo II & D3 & 23 th \\
\hline$R-4 b$ & 29 th & BP Juwana & D3 & 7 th \\
\hline $\mathrm{R}-4 \mathrm{c}$ & 46 th & BP Winong I & D3 & 24 th \\
\hline $\mathrm{R}-4 \mathrm{~d}$ & 34 th & BP Gabus II & D3 & 9 th \\
\hline $\mathrm{R}-4 \mathrm{e}$ & 35 th & BP Dukuhseti & D3 & 9 th \\
\hline \multicolumn{5}{|c|}{ Informan Triangulasi } \\
\hline $\mathrm{R}-1$ & 50 th & Ka.Kesga & S1 (SKM) & 8 th \\
\hline $\mathrm{R}-2 \mathrm{a}$ & 49 th & KP Gabus II & S2 (M.Kes.) & 6 th \\
\hline $\mathrm{R}-2 \mathrm{~b}$ & 43 th & KP Dukuhseti & S2 (M.Kes.) & 22 th \\
\hline $\mathrm{R}-3 \mathrm{a}$ & 34 th & DP Gabus II & S1 (Dokter umum) & 6 th \\
\hline$R-3 b$ & 35 th & DP Dukuhseti & S1 (Dokter umum) & 4 th \\
\hline
\end{tabular}

\section{Pelayanan Antenatal K4 di Puskesmas}

Pelayanan antenatal K4 dilaksanakan dengan berpedoman pada standar pelayanan minimal kebidanan di Puskesmas, yang mengacu pada petunjuk teknis dari Kemenkes RI dan target yang ditetapkan oleh Dinas Kesehatan Kabupaten Pati. SPM ini kemudian dituangkan kembali ke petunjuk operasional dengan keputusan kepala Puskesmas.

Pelayanan antenatal K4 di Puskesmas dilakukan oleh ibu hamil minimal 1 kali. Pedoman yang digunakan dalam pelayanan $\mathrm{K} 4$ adalah standar pelayanan 10T. Hasil wawancara dengan bidan disajikan pada Tabel 2 .

Tabel 2.

Hasil Wawancara Mendalam pada Bidan dalam Pelayanan K4 di Puskesmas

\begin{tabular}{|c|c|}
\hline Informan & Jawaban \\
\hline $\mathrm{R}-4 \mathrm{a}$ & $\begin{array}{l}\text { Bidan mengatakan untuk pelayanan K4 memang diharapkan dari ibu hamilnya periksa } \\
\text { di Puskesmas walaupun hanya satu kali. Itu untuk semua ibu hamil baik untuk risiko } \\
\text { tinggi maupun tidak risiko tinggi agar diperiksa oleh dokter. }\end{array}$ \\
\hline$R-4 b$ & $\begin{array}{l}\text { Bidan mengatakan pelayanan K4 sudah di Puskesmas dan dilakukan oleh dokter untuk } \\
\text { mendeteksi dini terjadinya risiko. Pelayanan K4 yang dilakukan bidan pada ibu hamil } \\
\text { adalah pemeriksaan kehamilan dan laborat misal cek HB, GD, protein urine, HBSAg. }\end{array}$ \\
\hline $\mathrm{R}-4 \mathrm{c}$ & $\begin{array}{l}\text { Bidan mengatakan pelayanan K4 sudah di Puskesmas. Pelayanan K4 yang dilakukan } \\
\text { bidan pada setiap ibu hamil yang pelayanan k4 di Puskesmas itu selain pelayanan seper- } \\
\text { ti biasa (K1 dan K2) ditambah dengan pemeriksaan laborat diantaranya HB, Protein, } \\
\text { HBSAg dan pemeriksaan dokter Puskesmas. }\end{array}$ \\
\hline$R-4 d$ & $\begin{array}{l}\text { Bidan mengatakan pelayanan } \mathrm{K} 4 \text { dilakukan dengan } 10 \mathrm{~T} \text {, termasuk pemeriksaaan labo- } \\
\text { ratorium oleh bidan dan dokter untuk konsultasi. }\end{array}$ \\
\hline $\mathrm{R}-4 \mathrm{e}$ & $\begin{array}{l}\text { Bidan mengatakan pelayanan K4 dilakukan oleh dokter dan bidan yang mengacu pada } \\
\text { 10T. }\end{array}$ \\
\hline Kesimpulan & $\begin{array}{l}5 \text { informan menyatakan bahwa pelayanan K4 di Puskesmas untuk ibu hamil baik risiko } \\
\text { tinggi maupun tidak dilakukan oleh bidan dan dokter. }\end{array}$ \\
\hline
\end{tabular}


Berdasarkan Tabel 2, diketahui bahwa sebagian pelayanan K4 di Puskesmas sudah dilakukan oleh dokter puskesmas dan dibantu bidan sejak sekitar awal bulan Januari tahun 2014. Pelayanan antenatal K4 di Puskesmas menggunakan SPM yang mengacu pada petunjuk teknis yang dikeluarkan oleh Kemenkes RI. Implementasi yang diberikan pada ibu hamil berupa pelayanan 10T. Pelayanan antenatal K4 merupakan cara untuk memantau kesehatan ibu hamil normal dan mendeteksi komplikasi kehamilan. Ketika dalam proses memberikan pelayanan ditemukan atau dicurigai pasien risiko tinggi maka bidan berkolaborasi dengan dokter untuk melakukan rujukan. Rujukan hanya boleh dibuat oleh dokter Puskesmas.

Terkait pelayanan K4 di Puskesmas dibenarkan oleh kepala Puskesmas (R-2a) sesuai kutipan wawancara sebagai berikut:

“...pelayanan K4 itu ya termasuk pemeriksaan lab, kalau bidan itu ya 10T..."

Pelayanan K4 di Puskesmas bertujuan untuk mendeteksi dini atau skrining awal terkait dengan sistem rujukan untuk mencegah adanya komplikasi dalam kehamilan dan per- salinan. Kebanyakan frekuensi kunjungan ibu hamil (K4) di Puskesmas hanya dilakukan 1 kali saja sebelum persalinan. Ibu hamil umumnya periksa dulu ke bidan desa atau bidan praktek baru kemudian ke Puskesmas untuk bersalin. Pernyataan tersebut diperkuat oleh penyataan informan triangulasi R-3a sesuai kutipan wawancara sebagai berikut:

“... malah kami di sini memaklumi kalau kadang permintaan ibu hamil minta diperiksa oleh bidan saja, jadi $k 4$ ya di bidan 1 kali dan paling tidak kami yang di Puskesmas 1 kali..."

\section{Pelayanan Pertolongan Persalinan di Puskesmas}

Pertolongan persalinan yang fisiologis atau bersifat normal ditangani oleh bidan Puskesmas. Pelayanan pertolongan persalinan di Puskesmas menggunakan standar Asuhan Persalinan Normal (APN). Jika ibu hamil termasuk risiko tinggi dan perlu dirujuk maka bidan akan konsultasi dengan dokter. Hasil wawancara mendalam dengan bidan terkait dengan pertolongan persalinan di Puskesmas dapat dilihat pada Tabel 3.

Tabel 3.

Hasil Wawancara Mendalam pada Bidan terkait Pertolongan Persalinan di Puskesmas

\begin{tabular}{|c|c|}
\hline Informan & Jawaban \\
\hline $\mathrm{R}-4 \mathrm{a}$ & $\begin{array}{l}\text { Bidan mengatakan semua bidan di Puskemas melakukan pertolongan persalinan di } \\
\text { Puskesmas. Pertolongan persalinan dilakukan dengan APN. }\end{array}$ \\
\hline$R-4 b$ & $\begin{array}{l}\text { Bidan mengatakan pertolongan persalinan dilakukan di Puskesmas oleh bidan, perto- } \\
\text { longan persalinan fisiologis dengan APN, yang masuk patologis dari awal terdeteksi } \\
\text { pasien dianjurkan untuk bersalin di rumah sakit. }\end{array}$ \\
\hline $\mathrm{R}-4 \mathrm{c}$ & $\begin{array}{l}\text { Bidan mengatakan pelayanan Pertolongan persalinan di Puskesmas Melalui penapisan } \\
\text { dan APN. }\end{array}$ \\
\hline $\mathrm{R}-4 \mathrm{~d}$ & $\begin{array}{l}\text { Bidan mengatakan pertolongan persalinan dilakukan di Puskesmas oleh bidan, pelayan- } \\
\text { an pertolongan ya dengan asuhan persalinan normal, kalau yang masuk patologis ya di } \\
\text { rujuk ke rumah sakit. }\end{array}$ \\
\hline$R-4 e$ & $\begin{array}{l}\text { Bidan mengatakan bahwa pertolongan persalinan biasa dilakukan sesuai dengan pena- } \\
\text { pisan APN. }\end{array}$ \\
\hline Kesimpulan & $\begin{array}{l}\text { Pelayanan pertolongan persalinan di Puskesmas masih dilakukan oleh bidan, dalam } \\
\text { melakukan pertolongan persalinan bidan harus menggunakan asuhan persalinan nor- } \\
\text { mal/APN. Jika ditemukan penyulit dalam persalinan bidan kolaborasi dengan dokter } \\
\text { puskesmas untuk membuat surat rujukan. }\end{array}$ \\
\hline
\end{tabular}


Pernyataan tersebut dibenarkan oleh informan triangulasi R3-a. Berikut kutipan hasil wawancaranya:

“... ya, biasanya kalau persalinan, bidan yang menangani, tapi memang yang fisiologis. Ada dokter juga paling tanya terkait konsultasi atau rujuk pasien bila terdapat kegawatdaruratan atau kesulitan selama proses persalinan....." (R3-a)

Pertolongan persalinan diupayakan dilakukan di tempat pelayanan kesehatan dengan fasilitas kesehatan yang memadai. Kondisi geografis dan stigma masyarakat yang menjadikan pertolongan persalinan kadang terpaksa dilakukan di Bidan Praktik Mandiri, bukan di Puskesmas. Bidan Praktik Mandiri selalu siap di tempat selama 24 jam. Adapun Puskesmas yang belum menerima rawat inap, harus mencari tenaga kesehatan terlebih dahulu jika ingin bersalin di luar jam kerja. Hal ini terjadi karena di Puskesmas non rawat inap tidak ada bidan atau tenaga kesehatan yang piket di luar jam kerja.

Hal ini sesuai dengan penelitian Aeni (2014) yang mengatakan bahwa faktor yang berhubungan dengan pemanfaatan pelayanan persalinan adalah wilayah/tempat tinggal res- ponden. Hasil penelitian ini selaras dengan penelitian Singh et al. (2012) yang menyimpulkan bahwa wilayah tempat tinggal bersama dengan tingkat pendidikan, pendapatan keluarga, agama, dan paparan media berkaitan secara signifikan dengan pemanfaatan pelayanan persalinan yang aman. Hasil penelitian ini didukung oleh pernyataan triangulasi $\mathrm{R}-3 \mathrm{~b}$. Berikut kutipan wawancaranya:

“....tentunya keadaan geografis sangat mempengaruhi ya, maksudnya ya jarak Puskesmas ke rumah masyarakat, meskipun ada angkutan, tapikan dari ujung sana sampe sini, lumayan. Dengan terpaksa kami mengijinkan dalam keadaan darurat, meskipun sebenarnya tidak diperbolehkan ........"

\section{Pelaksanaan Program K4 di Puskesmas}

Pelaksanaan program K4 di Puskesmas terkait cakupan, target $\mathrm{K} 4$, dan upaya peningkatan cakupan K4 dapat dilihat pada Tabel 4. Berdasarkan tabel tersebut, sebagian besar informan mengatakan bahwa cakupan K4 yang diperoleh Puskesmas masih kurang. Kondisi ini terjadi karena ibu hamil yang seharusnya melakukan pemeriksaan antenatal K4 di

Tabel 4.

Gambaran Pelaksanaan Program K4 di Puskesmas terkait Cakupan, Target K4, dan Upaya Peningkatan Cakupan K4

\begin{tabular}{cl}
\hline Informan & \multicolumn{1}{c}{ Jawaban } \\
\hline R-4a & $\begin{array}{l}\text { Bidan mengatakan cakupan K4 yang ada di Puskesmas masih kurang, dan belum me- } \\
\text { menuhi target. Untuk memenuhi target tersebut bidan harus meningkatkan promosi } \\
\text { pelayanan di Puskesmas terutama pelayanan kehamilan. }\end{array}$ \\
R-4b & $\begin{array}{l}\text { Bidan mengatakan cakupan K4 yang ada di Puskesmas masih kurang karena masih ba- } \\
\text { nyak yang periksa ke selain Puskesmas. Upaya yang dilakukan dengan meningkatkan } \\
\text { promosi terutama tentang pelayanan kehamilan. }\end{array}$ \\
R-4c & $\begin{array}{l}\text { Bidan mengatakan cakupan K4 di Puskesmas masih kurang, masih jauh dari target yang } \\
\text { diharapkan. Perlu upaya promosi dalam pelayanan kehamilan. }\end{array}$ \\
R-4d & $\begin{array}{l}\text { Bidan mengatakan cakupan pelayanan K4 masih dirasa kurang dan target cakupan } \\
\text { masih kurang dari target yang ditetapkan. }\end{array}$ \\
R-4e & $\begin{array}{l}\text { Bidan mengatakan bahwa cakupan dan target belum terpenuhi. Perlu peningkatan pro- } \\
\text { mosi pelayanan kebidanan. }\end{array}$ \\
Kesimpulan & $\begin{array}{l}\text { 5 informan utama yang diwawancarai mengatakan bahwa cakupan dan target K4 di } \\
\text { Puskesmas belum terpenuhi. Upaya yang harus dilakukan untuk memenuhi target terse- } \\
\text { but bidan harus lebih meningkatkan promosi pelayanan di puskesmas terutama pela- } \\
\end{array}$ \\
& yanan kehamilan.
\end{tabular}


Puskesmas memilih datang ke dokter spesialis kandungan yang memiliki fasilitas lengkap seperti USG. Selain itu masih ada anggapan negatif dari masyarakat terkait layanan yang ada di Puskesmas. Masyarakat menganggap bahwa kualitas pelayanan di Puskesmas kurang memuaskan karena lamanya waktu tunggu untuk mendapatkan pelayanan antenatal dari bidan. Masyarakat harus mengantri dulu dari loket pendaftaran baru bisa ke pelayanan KIA.

Kondisi ini bertentangan dengan pendapat Johns (1994) dalam Supranto (2006) yang mengatakan bahwa kebutuhan pelanggan perlu diperhatikan. Salah satu kebutuhan pelanggan adalah kecepatan waktu pelayanan, khususnya yang berkaitan dengan waktu tunggu dan proses pelayanan. Lambatnya waktu tunggu dan waktu proses pelayanan dapat membuat ibu hamil kurang berminat untuk periksa ke Puskesmas. Stigma masyarakat mengenai kualitas pelayanan di Puskesmas menjadi tantangan bidan, dokter, maupun Kepala Puskesmas selaku pimpinan di Puskesmas. Pernyataan tersebut dibenarkan oleh informan triangulasi R2-b. “...kalau masalah cakupan, kurang ya... apalagi dengan target, target cakupannya yang diharapkan bisa dikatakan belum memenuhi target. Target pemerintah sekian persen, tapi jumlah ibu hamil yang berkunjung ke Puskesmas sedikit, banyak yang ke spesialis..." (R2-b).

Hal ini dikuatkan dengan pernyataan Kepala Puskesmas yang mengatakan bahwa memang target dari pemerintah harus dievaluasi, karena jauh dari cakupan yang ada.

"......antara estimasi target pemerintah yang masih tinggi dengan realita kunjungna $K 4$ ibu hamil di Puskesmas...".

Adapun pada Tabel 5, dapat diketahui bahwa upaya yang sudah dilakukan berupa pendekatan bidan desa kepada ibu hamil untuk mengajak sadar diri periksa ke pelayanan dasar yaitu Puskesmas. Pendekatan yang dapat dilakukan diantaranya dengan melakukan konseling kepada masyarakat, terutama pada ibu hamil terkait deteksi dini jika ada risiko-risiko kehamilan yang dialami. Bidan melakukan pertolongan persalinan pada kehamilan normal. Pelayanan antenatal K4 dan pertolongan persalinan dilaksanakan di Puskesmas sejak Januari 2014. Sebelum itu, ibu hamil bisa bebas

Tabel 5.

Respon Bidan Saat Diberlakukan Program K4 dan Pertolongan Persalinan di Puskesmas

\begin{tabular}{cl}
\hline Informan & \multicolumn{1}{c}{ Jawaban } \\
\hline R-4a & $\begin{array}{l}\text { Bidan mengatakan bahwa awal penerapan program K4 dan pertolongan Persalinan ha- } \\
\text { rus di Puskesmas yaitu sejak awal 2014 sekitar bulan Januari. }\end{array}$ \\
R-4b & $\begin{array}{l}\text { Bidan mengatakan bahwa program itu sudah ada sejak akhir tahun 2013, dimana awal } \\
\text { pelaksanaannya bulan Januari 2014. }\end{array}$ \\
R-4c & Bidan mengatakan bahwa pelaksanaan program pada bulan Januari 2014. Respon bidan \\
& terutama bidan praktik mandiri ataupun bidan desa ada yang keberatan. \\
R-4d & Bidan mengatakan penerapan program K4 dan pertolongan persalinan di Puskesmas \\
& pada bulan Januari 2014 dan respon bidan praktik pada awalnya sangat keberatan. \\
R-4e & $\begin{array}{l}\text { Bidan mengatakan bahwa program K4 dan pertolongan persalinan di Puskesmas di- } \\
\text { laksanakan sejak Januari 2014. }\end{array}$ \\
Kesimpulan & $\begin{array}{l}5 \text { informan utama yang diwawancarai seluruhnya mengatakan bahwa mulai diberla- } \\
\text { kukan program K4 dan pertolongan persalinan di Puskesmas sejak Januari 2014. Res- } \\
\text { pon bidan praktik terhadap program tersebut pada awalnya sangat keberatan atas ke- } \\
\text { bijakan yang diberlakukan. Namun seiring berjalannya waktu, secara perlahan mereka } \\
\text { menerima dengan alasan merasa lebih terbantu dan meringankan beban dan tanggung } \\
\text { jawab atas kewenangan secara mandiri. }\end{array}$ \\
\hline &
\end{tabular}


memeriksakan kehamilan dan menyiapkan persalinan di fasilitas kesehatan termasuk Bidan. Tanggapan bidan saat diberlakukan program pelayanan antenatal K4 dan pertolongan persalinan di Puskesmas disajikan dalam Tabel 5.

Hal ini sesuai dengan aturan Surat Edaran yang tertuju kepada Kepala UPT Puskesmas SeKabupaten Pati yang disahkan oleh Kepala Dinas Kesehatan Kabupaten Pati pada tanggal 2 Desember 2013, dimana salah satu isi perintah Surat Edaran bagi seluruh Puskesmas wilayah kerja Dinas Kesehatan Kabupaten Pati yaitu: 1) bidan hanya diperbolehkan menolong persalinan normal, jika ada bidan yang menolong persalinan dengan risiko tinggi maka akan dikenakan sanksi administrasi sampai dengan pencabutan ijin praktek; 2) pelayanan ANC (K1 s/d K3) dilaksanakan oleh bidan sedangkan pelayanan ANC (K4) dilaksanakan oleh dokter Puskesmas wilayah setempat; 3) keputusan merujuk pasien adalah wewenang dokter Puskesmas, oleh karena itu bidan harus konsultasi/ memberitahu kepada dokter Puskesmas bila ada ibu hamil dengan risiko tinggi sehingga dokter Puskesmas dapat memberikan keputusan untuk merujuk dan surat rujukan pasien harus ditandatangani oleh dokter Puskesmas.
Hal ini diperkuat oleh pernyataan oleh Kepala Puskesmas yang menyatakan bahwa:

“.... Pelaksanaan program $\mathrm{K} 4$ ini mulai dari sekitar awal bulan Januari kami menerapkannya. (R3-b).

Program K4 dan pertolongan persalinan di Puskesmas bertujuan untuk menurunkan angka kematian ibu. Awalnya bidan praktik ataupun bidan desa merasa keberatan atas kebijakan tersebut. Namun seiring berjalannya waktu, secara perlahan menerima karena meringankan beban dan tanggung jawab atas kewenangan secara mandiri. Adanya sistem pertolongan persalinan di Puskesmas dengan tenaga kesehatan dan fasilitas kesehatan lebih memadai diharapkan jumlah kematian ibu menurun.

Program pemeriksaan Antenatal Care (K4) di Puskesmas dan pertolongan persalinan diharuskan di Puskesmas ini merupakan salah satu upaya penurunan angka kematian ibu, Hal ini dijelaskan pada Tabel 6 mengenai manfaat dan kendala dalam pelaksanaan program $\mathrm{K} 4$ dan pertolongan persalinan di Puskesmas dalam rangka menurunkan Angka Kematian Ibu. Adanya kolaborasi bidan dengan dokter Puskesmas lebih meringankan tanggung jawab

Tabel 6.

Manfaat dan Kendala dalam Pelaksanaan Program K4 dan Pertolongan Persalinan di Puskesmas dalam Rangka Menurunkan Angka Kematian Ibu

\begin{tabular}{|c|c|}
\hline Informan & Jawaban \\
\hline $\mathrm{R}-4 \mathrm{a}$ & $\begin{array}{l}\text { Bidan mengatakan bahwa manfaat yang nyata dalam program ini adalah salah satu } \\
\text { upaya penurunan AKI yang cukup bagus dan kendalanya adalah kurangnya tenaga dok- } \\
\text { ter. }\end{array}$ \\
\hline$R-4 b$ & $\begin{array}{l}\text { Bidan mengatakan manfaat yang diperoleh adalah bidan dalam pelayanannya dibantu } \\
\text { oleh dokter Puskesmas, tetapi kendalanya adalah tenaga dokter yang masih kurang. }\end{array}$ \\
\hline $\mathrm{R}-4 \mathrm{c}$ & $\begin{array}{l}\text { Bidan mengatakan manfaatnya sangat signifikan dalam upaya penurunan AKI dan ham- } \\
\text { batannya yaitu masalah pasien yang sulit untuk mau periksa ke Puskesmas. }\end{array}$ \\
\hline $\mathrm{R}-4 \mathrm{~d}$ & $\begin{array}{l}\text { Bidan mengatakan bahwa manfaat yang nyata adalah dengan adanya kolaborasi dengan } \\
\text { dokter Puskesmas. Hambatannya adalah kurangnya tenaga dokter. }\end{array}$ \\
\hline $\mathrm{R}-4 \mathrm{e}$ & $\begin{array}{l}\text { Bidan mengatakan manfaatnya sangat berarti dalam upaya penurunan AKI dan ham- } \\
\text { batannya yaitu masalah pasien yang sulit untuk mau periksa ke Puskesmas. }\end{array}$ \\
\hline Kesimpulan & $\begin{array}{l}5 \text { informan utama yang diwawancarai mengatakan bahwa manfaatnya sangat berarti } \\
\text { dalam upaya penurunan angka kematian ibu, tetapi kendalanya adalah kurangnya tena- } \\
\text { ga dokter di Puskesmas. }\end{array}$ \\
\hline
\end{tabular}


bidan. Jika didapatkan kondisi ibu hamil dengan risiko tinggi, proses penentuan pengambilan keputusan atau sistem rujukan ditangani langsung oleh dokter Puskesmas. Hal ini diperkuat oleh informan triangulasi R2-a.

“...iya,... dalam hal ini, paling kalau bidan konsul, tapi biasanya by phone, konsultasi tentang kondisi ibu hamil itu ke bu dokter, dan kalau kolaborasi dengan dokter sperti ini malah bagus, tertangani..." (R2-a)

Kendala atau hambatan yang dihadapi selama ini adalah dengan diharuskan adanya kolaborasi dengan dokter, dokter harus bisa membagi waktu pelayanan atau mampu berpindah tempat ruang pelayanan di Puskesmas. Dokter harus melayani Antenatal Care di ruang kesehatan ibu dan anak, dan juga di ruang pelayanan poli umum. Hal ini diperkuat dengan pernyataan dokter Puskesmas (R3-a).

“...iya, saya harus kesana-kemari, kan harus $A N C$, ke pemeriksaan yang disana juga gitu..." (R3-a).

\section{KESIMPULAN DAN SARAN}

\section{Kesimpulan}

Pelayanan K4 di Puskesmas dilaksanakan oleh bidan dan dokter dengan standar operasionalnya dikenal standar minimal (10T). Pertolongan persalinan sebagian besar sudah di Puskesmas oleh bidan dan dokter (on call). Cakupan target kunjungan K4 di Puskesmas masih kurang atau belum terpenuhi. Kondisi ini terjadi karena ibu hamil yang seharusnya periksa antenatal K4 di Puskesmas lebih memilih periksa pada dokter spesialis kandungan yang memiliki fasilitas lengkap termasuk USG. Masyarakat menganggap layanan yang ada di Puskesmas kurang bagus kualitasnya, fasilitas dan pelayanannya juga kurang memuaskan. Program K4 dan pertolongan persalinan di Puskesmas diberlakukan sejak Januari 2014. Tenaga kesehatan seperti bidan, dokter, dan Kepala Puskesmas mendukung keberlanjutan program K4 dan pertolongan persalinan di Puskesmas.

\section{Saran}

Perlu peningkatan jumlah petugas kesehatan khususnya dokter pada setiap Puskesmas untuk ditempatkan pada pelayanan K4. Kebijakan program cakupan target, perlu dikaji ulang. Perlu dilakukan koreksi pelaksanaan bila ada yang tidak sesuai. Perlu ditingkatkan lagi promosi pelayanan dan keaktifan tenaga bidan dalam melaksanakan pelayanan K4. Petugas kesehatan perlu melakukan kunjungan rumah pada ibu hamil yang tidak melakukan kunjungan kehamilan keempat dan kemudian menggali alasan tidak datang melakukan pemeriksaan kehamilan ke Puskesmas. Perlu adanya evaluasi terhadap pelaksanaan pelayanan antenatal dan mengikuti perkembangan ilmu dan teknologi terkini dalam meningkatkan kepuasan masyarakat.

\section{DAFTAR PUSTAKA}

Agustino, L. (2016). Dasar-Dasar Kebijakan Publik (Edisi Revisi). Bandung: Alfabeta.

Anggraeni, M.D., Saryono. (2010). Metodologi Penelitian Kualitatif dalam Bidang Kesehatan. Yogyakarta: Nuha Medika.

Asuhan Persalinan Normal. (2014). Buku Acuan Persalinan Normal. Jakarta: JNPK- KR.

Departemen Kesehatan Republik Indonesia. (2011). Penyediaan Fasilitas Program Kesehatan Ibu dan Anak. Jakarta: Departemen Kesehatan RI

Dinas Kesehatan Kabupaten Pati. (2019). Profil Kesehatan Kabupaten Pati Tahun 2018. Pati: Dinas Kesehatan Kabupaten Pati.

Dinas Kesehatan Provinsi Jawa Tengah. (2019). Profil Kesehatan Provinsi Jawa Tengah 2018. Semarang: Dinas Kesehatan Provinsi Jawa Tengah.

Kementerian Kesehatan Republik Indonesia (2018). Profil Kesehatan Indonesia 2017. Jakarta: Kementerian Kesehatan Republik Indonesia

Kementerian Kesehatan Republik Indonesia. (2012). Pedoman Pelayanan Antenatal Terpadu Edisi Kedua. Jakarta: Kementerian Kesehatan Republik Indonesia. 
Key, F. (2018). Maternal Mortality. Diakses 16 February 2018. https://www.who .int/ newsroom/factsheets/detail/maternalmortality.

Kusmiyati, Y. (2010). Asuhan Kehamilan. Yogyakarta: Fitramaya.

Moleong, L.J. (2013). Metode Penelitian Kualitatif Edisi Revisi. Bandung: PT Remaja Rosdakarya Offset.

Nugroho, R. (2014). Kebijakan Publik Formulasi, Implementasi dan Evaluasi. Jakarta: Elex Media Komputindo.

Nurasiah, Ai., Rukmawati, A., Badriah, D.L. (2013). Asuhan Persalinan Normal bagi Bidan. Bandung: Refika Aditama.

Aeni, N. (2014). Pemilihan Pelayanan Persalinan dan Perawatan Pascapersalinan (PNC). Jurnal Litbang Media Informasi Penelitian dan Pengembangan IPTEK. X (1), 52-63. https://doi.org/10.33658/ jl.v10i1.77

Peraturan Menteri Kesehatan Republik Indonesia Nomor 4 Tahun 2019 Tentang Standar Teknis Pemenuhan Mutu Pelayanan Dasar pada Standar Pelayanan Minimal Bidang Kesehatan.

Prawirohardjo, S. (2014). Ilmu Kebidanan. Jakarta: Bina Pustaka Sarwono Prawirohardjo.

Supranto, J. (2006). Pengukuran Tingkat Kepuasan Pelanggan untuk Menaikkan Pangsa Pasar. Jakarta: PT. Rineka Cipta

Rahmawati, L.(2013). Analisis Faktor-faktor yang Mempengaruhi Keberhasilan Pencapaian Cakupan K4 di Puskesmas Rowosari Semarang. Jurnal Kesehatan Masyarakat. 02(01) Januari 2013. https:// media.neliti.com/media/publications/ 18752-ID-analisis-faktor-faktor-yangmempengaruhi -keberhasilan-pencapaian -cakupan-k4-di-p.pdf
Singh. P.K; Rai, R.K; Algarajan, M; Singh, L. (2012). Determinant of Maternity care Services Utilization among Married Adolescent in Rural India. Plos. One. 7 (2).E31666. Diakses 14 Oktober 2019. https://journals.plos.org/losone/article? id=10.1371/journal.pone.0031666

Sumiati, S. (2012). Faktor-Faktor yang berhubungan dengan Kunjungan Pemeriksaan Kehamilan K4 di Puskesmas dengan Sindangratu Kabupaten Garut Propinsi Jawa Barat Tahun 2012. Skripsi. Jakarta: Universitas Indonesia

Sugiyono. (2012). Metode Penelitian Kuantitatif Kualitatif dan R\&D. Bandung: Alfabeta.

WHO. (2014). Maternal Mortality. World Health Organization. https://www. who.int/ newsroom/fact-sheet/detail/-15-052014-world-health-Maternal-Mortality2015.

Wiknjosastro, H. (2011). Ilmu Kebidanan. Jakarta: Yayasan Bina Pustaka Sarwono Prawirohardjo.

\section{BIODATA PENULIS}

Penulis Pertama Ulin Nafiah,S.ST., M.Kes. Lahir 20 Juli 1982 di Pati, D3 Kebidanan dari Akademi Kebidanan Duta Dharma Pati, D4 Bidan Pendidik dari Politeknik Kesehatan Semarang, dan Magister Kesehatan Masyarakat dari Universitas Diponegoro Semarang. Saat ini bekerja di Akademi Kebidanan Duta Dharma Pati.

Penulis Kedua Indayana S.ST.,M.Kes. Lahir pada 22 Oktober 1989 di Kudus, D3 Kebidanan dari Akademi Kebidanan Pemkab Kudus, D4 dari Sekolah Tinggi Ilmu Kesehatan Karya Husada Semarang, Magister Kesehatan Masyarakat dari Universitas Sebelas Maret Surakarta. Bekerja di AKBID Duta Dharma dari Tahun 2014 sampai tahun 2017. Tahun 2018 sampai sekarang bekerja di Akademi Kebidanan Muslimat NU Kudus. 
